\title{
The global prevalence of fusidic acid resistance in clinical isolates of Staphylococcus aureus: a systematic review and meta-analysis
}

\author{
Bahareh Hajikhani ${ }^{1}$, Mehdi Goudarzi ${ }^{1 \dagger}$, Sareh Kakavandi', Sana Amini', Samira Zamani', Alex van Belkum², \\ Hossein Goudarzi ${ }^{1}$ and Masoud Dadashi ${ }^{3,4^{*}}$
}

\begin{abstract}
Background and aim: Staphylococcus aureus (S. aureus) is one of the most common pathogens causing nosocomial and community-acquired infections with high morbidity and mortality rates. Fusidic acid has been increasingly used for the treatment of infections due to methicillin-susceptible S. aureus (MSSA) and methicillin-resistant S. aureus (MRSA). The present study aimed to determine the precise prevalence of fusidic acid resistant MRSA (FRMRSA), fusidic acid resistant MSSA (FRMSSA), and total fusidic acid resistant S. aureus (FRSA) on a global scale.

Methods: Several international databases including Medline, Embase, and the Web of Sciences were searched (2000-2020) to discern studies addressing the prevalence of FRSA, FRMRSA, and FRMSSA. STATA (version14) software was used to interpret the data.

Results: Of the 1446 records identified from the databases, 215 studies fulfilled the eligibility criteria for the detection of FRSA (208 studies), FRMRSA (143 studies), and FRMSSA (71 studies). The analyses manifested that the global prevalence of FRSA, FRMRSA, and FRMSSA was $0.5 \%, 2.6 \%$ and $6.7 \%$, respectively.

Conclusion: This meta-analysis describes an increasing incidence of FRSA, FRMSSA, and FRMRSA. These results indicate the need for prudent prescription of fusidic acid to stop or diminish the incidence of fusidic acid resistance as well as the development of strategies for monitoring the efficacy of fusidic acid use.
\end{abstract}

Keywords: Fusidic acid, Staphylococcus aureus, MRSA, Meta-analysis

\section{Introduction}

Staphylococcus aureus (S. aureus) is one of the most important causative agents in a wide range of clinical syndromes, from the skin and soft tissue infections to infective endocarditis and bacteremia as well as different prosthetic device-related infections which are reported largely worldwide [1-3]. This bacterial species can become resistant to many antibiotics, using different

\footnotetext{
*Correspondence: m_d6512@yahoo.com; masoud.dadashi@sbmu.ac.ir

${ }^{\dagger}$ Mehdi Goudarzi: co-first author

${ }^{3}$ Department of Microbiology, School of Medicine, Alborz University of Medical Sciences, Karaj, Iran

Full list of author information is available at the end of the article
}

mechanisms. Acquisition of mobile genetic resistance elements by horizontal gene transfer, mutations of antibiotic targets, and overexpression of endogenous efflux pumps are among the most important mechanisms [4-6]. Knowing how antibiotics work and how bacteria become resistant, as well as generating accurate statistics on the rate of antibiotic resistance in different parts of the world, are important for medical management and therapeutic decisions. Furthermore, it can help in the development of practical infection control methods as well as the prevention of bacterial resistance spreading. Fusidic acid (FA) is one of the important antibacterial agents that requires ongoingevaluation of its mode of action and original author(s) and the source, provide a link to the Creative Commons licence, and indicate if changes were made. The images or other third party material in this article are included in the article's Creative Commons licence, unless indicated otherwise in a credit line to the material. If material is not included in the article's Creative Commons licence and your intended use is not permitted by statutory regulation or exceeds the permitted use, you will need to obtain permission directly from the copyright holder. To view a copy of this licence, visit http://creativecommons.org/licenses/by/4.0/. The Creative Commons Public Domain Dedication waiver (http://creativeco mmons.org/publicdomain/zero/1.0/) applies to the data made available in this article, unless otherwise stated in a credit line to the data. 
assessment of its resistance rate to help improve treatment strategies, particularly in the caseof staphylococcal infections. FA, derived from the fungus Fusidium coccineum (in 1960), shows moderate activity against most Gram-positive bacteria including staphylococci and also covering methicillin-resistant S. aureus (MRSA), and some anaerobic Gram-negative organisms [7]. It is generally used topically for the treatment of $S$. aureus skin infections. Different creams and ointments containing FA are commercially available. Intravenous and oral preparations of this antibiotic are also used as anti-staphylococcal agents to treat persistent skin infections as well as chronic bone and joint infections [7, 8]. In addition, FA is an important and valuable alternative to vancomycin to combat resistant organisms [4]. FA primarily has bacteriostatic effects, although it may be bactericidal in high concentrations [9]. FA is a specific inhibitor of the elongation factor G (EF-G) which is essential in the peptide translocation step during protein synthesis. FA inhibits the GTPase function of EF-G after binding to its target and then prevents further elongation of the polypeptide chain [10]. Plasmid mediated resistance resulted from decreased bacterial cell wall or membrane permeability. Chromosomal mutations expressed in EF-G and its associated proteins (fusB, fus $\mathrm{C}$, and fusD) as well as a mutation in fusA, and fusE genes have been described as relevant factors in FA resistance [11,13] The lack of cross-resistance with other important classes of antibiotics (beta-lactams, macrolides and, aminoglycosides) is an important feature of this antibiotic which may be due to the widely different chemical structures of these agents [10]. Nonetheless, increased antibiotic usage, combined with increased therapy duration, has been linked to an increased rate of FA resistance among $S$. aureus isolates [12]. FA resistance rates were evaluated in 13 European countries. The results of this survey showed that the overall prevalence of resistance to FA was $10.7 \%$ among S. aureus isolates. The highest rate of resistance (62.4\%) was observed among isolates from Greece [14]. Although several studies have examined the resistance FA among of S. aureus strains, a comprehensive study reporting global data is not available. So, the current study aims to evaluate the dissemination and prevalence of all FA resistant $S$. aureus (FRSA), and also FA resistant MRSA (FRMRSA), and FA resistant MSSA (FRMSSA), among clinical isolates in a meta-analysis and systematic review.

\section{Methods}

\section{Literature search}

A systematic search was conducted to evaluate the prevalence of FRSA among clinical strains based on selected keywords (Staphylococcus aureus, Staphylococcus, S. aureus, fusidic acid, sodium fusidate, and fucidin) using three main electronic databases including Medline (via PubMed), Embase, and Web of Science (2000-2020). Original articles published in English that provided the prevalence or incidence of FRSA, FRMRSA, and FRMSSA were selected for further analysis. We also searched the bibliographies for additional relevant articles.

\section{Inclusion and exclusion criteria}

All original papers presenting cross-sectional studies on the prevalence of FRSA, FRMRSA, and FRMSSA were included. All selected studies were screened based on titles, abstracts, and full texts consecutively. Studies were included in our analysis based on the following criteria: (1) original articles that provided sufficient data on FRSA; (2) used standard methods; (A) disk diffusion method; (B) agar dilution, microdilution, and macrodilution methods or E-test; and (C) molecular methods to detect FRSA, FRMRSA and FRMSSA according to the CLSI (2020) guidelines [15]. The exclusion criteria were: (1) articles studying non-human samples; (2) studies considering; (A) FA resistant bacteria except S. aureus; (B) other types of antibiotic resistance except FA; (3) review articles; (4) abstracts reported in conferences; and (5) duplicate article.

\section{Data extraction and definitions}

The author's last name, date(s) of the investigation, year of publication, country/continent, total number of $S$. aureus, MRSA, MSSA, FRSA, FRMRSA and FRMSSA as well as a detection method and the source of isolates were extracted from the enrolled studies. The prevalence of FRSA, FRMRSA, and FRMSSA isolates was evaluated as well. Two independent researchers recorded the data to avoid bias.

\section{Quality assessment}

All evaluated studies were subjected to a quality assessment (designed by the Joanna Briggs Institute), and only high-quality ones were selected for our final analysis [16].

\section{Meta-analysis}

STATA (version 14.0) software was used to analyze the extracted data. The data were pooled using the fixedeffects model (FEM) [17] and the random-effects model (REM) [18]. Statistical heterogeneity was assessed using the Cochran Q and I2 statistical methods [19].

\section{Results}

\section{Characteristics of included studies}

After removing duplicates, we identified a total of 1446 articles in the databases. Based on the title and abstract evaluation in secondary screening, 471 of the chosen 
ones were excluded (see Fig. 1 which also includes the reasons for rejection). In the next step, upon full text research, 208, 143, 71 articles were included for FRSA, FRMRSA, and FRMSSA, respectively [11, 20-233]. The characteristics of the included articles are shown in Additional file 1: Tables S1, S2, and S3.

\section{The prevalence of FRSA, FRMRSA and FRMSSA \\ among clinical isolates}

The pooled and averaged prevalence of FRSA, FRMRSA and FRMSSA were 0.5 [(95\% CI) 4.6-5.4] among 157,220 $S$. aureus isolates, 2.6 [(95\% CI) 2.3-2.9] among 94,238 S. aureus isolates, 6.7 [(95\% CI) 5.4-7.9] among 11,992 S. aureus isolates, respectively. Also, the pooled prevalence of FRMRSA among 50,078 MRSA isolates and FRMSSA among 70,438 MSSA isolates was 5.8 [(95\% CI) 5.0-6.6] and 3.0 [(95\% CI) 2.6-3.5], respectively (Tables 1, 2).

\section{The prevalence of FRSA, FRMRSA and FRMSSA in different study periods}

To determine the longitudinal changes in the prevalence of FRSA, FRMRSA, and FRMSSA across recent years, we designed subgroups across three periods (before 2000, 2000-2009, and 2010-2020) (Tables 1, 2). As shown in Tables 1 and 2, the incidence rate of FRSA and FRMRSA strains gradually increased from $4.0 \%$ (95\% CI 3.4-4.5) of $3478 / 90,563 \mathrm{~S}$. aureus isolates and $1.4 \%$ (95\% CI 1.1-1.8) of $547 / 39,499$ MRSA isolates before 2000 to $5.6 \%$ (95\% CI $4.9-6.2)$ of $2834 / 46,134$ isolates and $2.9 \%$ (95\% CI $2.3-3.4$ ) of $1094 / 41,157$ isolates in 2000-2009, reaching $5.2 \%$ (95\% CI 4.4-6.1) of $1250 / 20,523$ S. aureus isolates

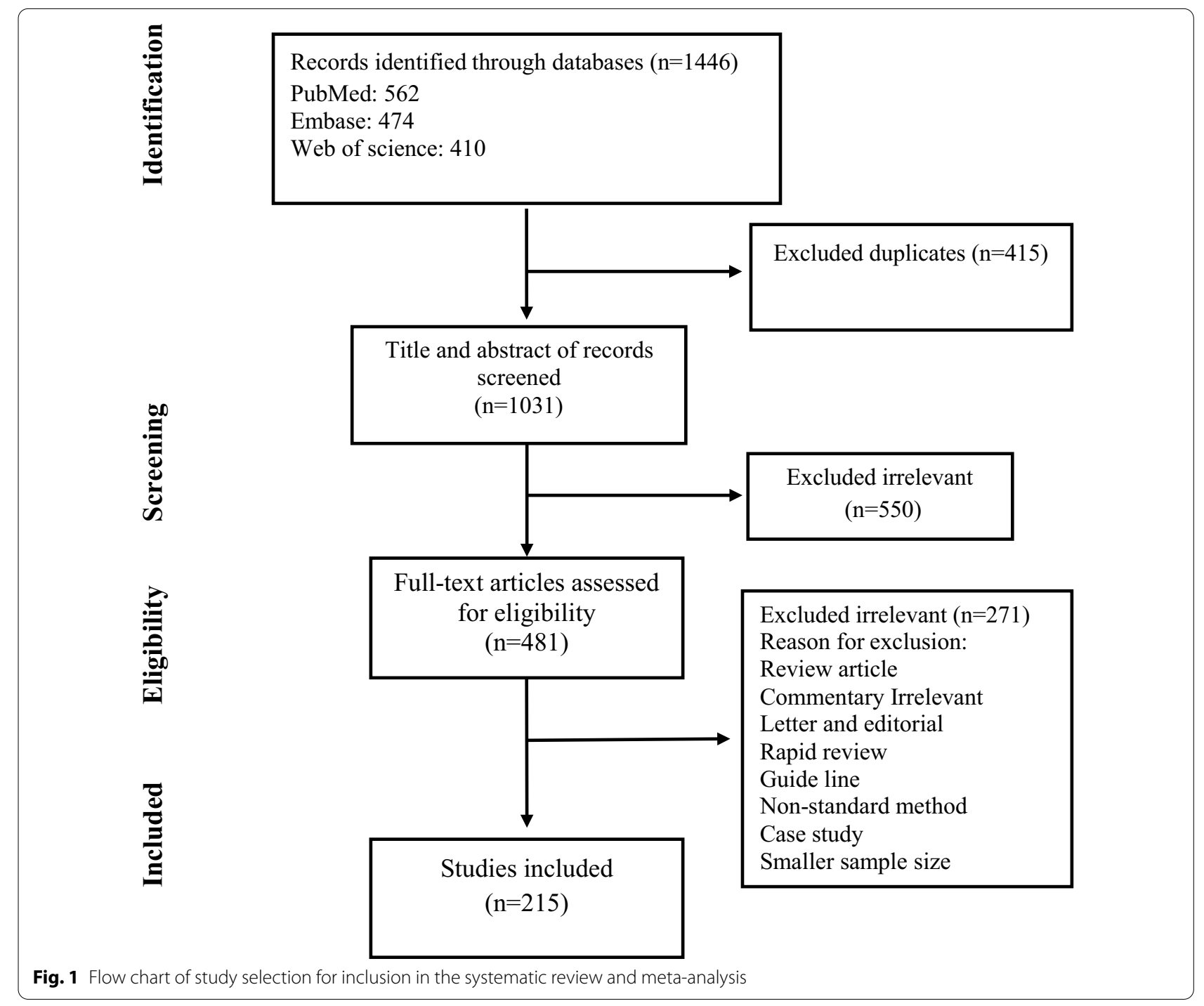


Table 1 Prevalence of FRSA, FRMRSA and FRSSA based on study periods and continents

\begin{tabular}{|c|c|c|c|c|}
\hline Category & Subcategory & No. studies & No. strains & Prevalence (\%) $(95 \% \mathrm{Cl})$ \\
\hline \multicolumn{5}{|l|}{ FRSA } \\
\hline Overall & FRSA/S. aureus & 120 & $7562 / 157,220$ & $0.5(4.6-5.4)$ \\
\hline \multirow[t]{3}{*}{ Study period } & Before 2000 & 26 & $3478 / 90,563$ & $4.0(3.4-4.5)$ \\
\hline & 2000-2009 & 55 & $2834 / 46,134$ & $5.6(4.9-6.2)$ \\
\hline & 2010-2020 & 39 & $1250 / 20,523$ & $5.2(4.4-6.1)$ \\
\hline \multirow[t]{5}{*}{ Continent } & Asia & 32 & $768 / 11,239$ & $5.6(4.6-6.6)$ \\
\hline & Europe & 69 & $5519 / 122,267$ & $4.7(4.3-5.2)$ \\
\hline & America & 9 & $408 / 7010$ & $5.5(3.4-7.5)$ \\
\hline & Africa & 3 & $58 / 723$ & $5.5(0.6-10.4)$ \\
\hline & Oceania & 7 & $809 / 15,981$ & $5.0(3.7-6.3)$ \\
\hline \multicolumn{5}{|l|}{ FRMRSA } \\
\hline Overall & FRMRSA/S. aureus & 79 & $2193 / 94,238$ & $2.6(2.3-2.9)$ \\
\hline \multirow[t]{3}{*}{ Study period } & Before 2000 & 14 & $547 / 39,499$ & $1.4(1.1-1.8)$ \\
\hline & 2000-2009 & 35 & $1094 / 41,157$ & $2.9(2.3-3.4)$ \\
\hline & $2010-2020$ & 30 & $552 / 13,582$ & $3.2(2.3-4.1)$ \\
\hline \multirow[t]{5}{*}{ Continent } & Asia & 27 & $296 / 7330$ & $3.0(2.1-4.0)$ \\
\hline & Europe & 36 & $1449 / 77,695$ & $1.9(1.5-2.2)$ \\
\hline & America & 7 & $302 / 4798$ & $4.3(1.5-7.2)$ \\
\hline & Africa & 6 & $111 / 1334$ & $6.8(3.6-9.9)$ \\
\hline & Oceania & 3 & $35 / 3081$ & $1.1(0.8-1.5)$ \\
\hline Overall & FRMRSA/MRSA & 72 & $3211 / 50,078$ & $5.8(5.0-6.6)$ \\
\hline \multirow[t]{3}{*}{ Study period } & Before 2000 & 19 & $1410 / 20,768$ & $5.9(4.2-7.5)$ \\
\hline & 2000-2009 & 31 & $1127 / 20,601$ & $5.0(4.0-6.1)$ \\
\hline & 2010-2020 & 22 & 674/8709 & $6.8(5.3-8.3)$ \\
\hline \multirow[t]{5}{*}{ Continent } & Asia & 26 & $1155 / 11,414$ & $6.4(4.4-8.3)$ \\
\hline & Europe & 33 & $1637 / 32,906$ & $1.9(1.5-2.2)$ \\
\hline & America & 7 & 295/4130 & $5.3(3.2-7.4)$ \\
\hline & Africa & 2 & $5 / 138$ & $3.6(0.5-6.7)$ \\
\hline & Oceania & 4 & $119 / 1490$ & $1.1(0.8-1.5)$ \\
\hline \multicolumn{5}{|l|}{ FRMSSA } \\
\hline Overall & FRMSSA/S. aureus & 9 & 939/11,992 & $6.7(5.4-7.9)$ \\
\hline \multirow[t]{3}{*}{ Study period } & Before 2000 & 2 & $432 / 5425$ & $8.0(7.2-8.7)$ \\
\hline & 2000-2009 & 4 & 489/6153 & $7.1(5.3-8.9)$ \\
\hline & 2010-2020 & 3 & $18 / 414$ & $8.0(7.2-8.7)$ \\
\hline \multirow[t]{5}{*}{ Continent } & Asia & 2 & $9 / 227$ & $4.0(1.1-7.0)$ \\
\hline & Europe & 6 & $923 / 11,550$ & $7.8(6.8-8.7)$ \\
\hline & America & $N R$ & $N R$ & $N R$ \\
\hline & Africa & $N R$ & $N R$ & $N R$ \\
\hline & Oceania & 1 & $7 / 215$ & $3.3(9.0-5.6)$ \\
\hline Overall & FRMSSA/MSSA & 42 & $2437 / 70,438$ & $3.0(2.6-3.5)$ \\
\hline \multirow[t]{3}{*}{ Study period } & Before 2000 & 24 & $1825 / 57,798$ & $2.9(2.5-3.4)$ \\
\hline & 2000-2009 & 10 & $497 / 8051$ & $3.8(1.6-6.1)$ \\
\hline & 2010-2020 & 8 & $115 / 4589$ & $2.8(1.8-3.7)$ \\
\hline \multirow[t]{5}{*}{ Continent } & Asia & 8 & $57 / 2845$ & $1.7(1.2-2.1)$ \\
\hline & Europe & 26 & $2234 / 62,854$ & $3.1(2.5-3.7)$ \\
\hline & America & 2 & $62 / 2178$ & $2.8(2.1-3.4)$ \\
\hline & Africa & 3 & $13 / 647$ & $1.9(0.3-3.5)$ \\
\hline & Oceania & 3 & 71/1914 & $3.6(2.7-4.4)$ \\
\hline
\end{tabular}


Table 2 Prevalence of FRSA, FRMRSA and FRSSA based on different countries

\begin{tabular}{|c|c|c|c|c|}
\hline Category & Subcategory & No. studies & No. strains & Prevalence (\%) $(95 \% \mathrm{Cl})$ \\
\hline \multicolumn{5}{|l|}{ FRSA } \\
\hline Overall & FRSA/S. aureus & 120 & $7562 / 157,220$ & $0.5(4.6-5.4)$ \\
\hline \multirow[t]{22}{*}{ Country } & Australia & 6 & $796 / 15,781$ & $4.8(3.4-6.2)$ \\
\hline & Belgium & 2 & $25 / 663$ & $3.6(2.2-5.0)$ \\
\hline & Canada & 5 & $376 / 6257$ & $6.3(3.2-9.3)$ \\
\hline & China & 4 & $206 / 2156$ & $5.3(0.6-10.0)$ \\
\hline & France & 7 & $132 / 3120$ & $5.0(3.2-6.8)$ \\
\hline & Germany & 6 & $94 / 2424$ & $4.7(2.8-6.6)$ \\
\hline & India & 2 & $6 / 173$ & $3.5(0.7-6.2)$ \\
\hline & Iran & 3 & $13 / 353$ & $3.4(1.5-5.3)$ \\
\hline & Israel & 2 & $8 / 220$ & $3.6(1.1-6.0)$ \\
\hline & Kuwait & 3 & $93 / 1370$ & $6.8(5.4-8.1)$ \\
\hline & Malaysia & 5 & $102 / 1956$ & $5.3(3.6-6.9)$ \\
\hline & Malta & 2 & $374 / 25$ & $6.5(4.0-9.1)$ \\
\hline & Netherland & 2 & $63 / 1193$ & $5.2(4.0-6.5)$ \\
\hline & Norway & 2 & $12 / 136$ & $8.3(3.7-12.9)$ \\
\hline & Poland & 2 & $10 / 291$ & $3.4(1.3-5.5)$ \\
\hline & Spain & 2 & $5 / 113$ & $4.2(0.5-8.0)$ \\
\hline & Sweden & 2 & $38 / 616$ & $5.4(3.6-7.2)$ \\
\hline & Switzerland & 2 & $18 / 317$ & $5.6(3.1-8.2)$ \\
\hline & Taiwan & 4 & 75/1134 & $5.9(1.9-9.9)$ \\
\hline & Turkey & 9 & $223 / 3319$ & $5.8(3.7-7.9)$ \\
\hline & UK & 22 & $4715 / 105,038$ & $4.8(4.1-5.5)$ \\
\hline & USA & 3 & $26 / 653$ & $3.7(2.3-5.2)$ \\
\hline \multicolumn{5}{|l|}{ FRMRSA } \\
\hline Overall & FRMRSA/S. aureus & 79 & 2193/94,238 & $2.6(2.3-2.9)$ \\
\hline \multirow[t]{16}{*}{ Country } & Australia & 2 & $33 / 2881$ & $1.1(0.8-1.5)$ \\
\hline & Canada & 4 & $276 / 4145$ & $4.5(0.2-8.9)$ \\
\hline & China & 4 & $5 / 295$ & $1.3(0.0-2.5)$ \\
\hline & France & 3 & $33 / 2141$ & $1.4(0.3-2.5)$ \\
\hline & Germany & 2 & $11 / 656$ & $2.0(0.0-4.5)$ \\
\hline & Greece & 2 & $5 / 142$ & $2.1(0.3-3.9)$ \\
\hline & Iran & 4 & $14 / 844$ & $1.2(0.4-1.9)$ \\
\hline & Korea & 2 & $19 / 653$ & $2.1(0.0-5.0)$ \\
\hline & Kuwait & 2 & $91 / 1427$ & $4.5(0.1-9.1)$ \\
\hline & Malaysia & 4 & $84 / 1877$ & $4.5(1.9-7.2)$ \\
\hline & Pakistan & 2 & $47 / 691$ & $4.9(0.2-12.7)$ \\
\hline & Poland & 2 & $8 / 338$ & $2.0(0.5-3.5)$ \\
\hline & Taiwan & 2 & $2 / 124$ & $0.9(0.0-2.1)$ \\
\hline & Turkey & 7 & 77/1324 & $5.3(2.7-7.9)$ \\
\hline & UK & 10 & $1167 / 67,758$ & $1.4(1.0-1.9)$ \\
\hline & USA & 3 & 26/653 & $3.7(2.3-5.2)$ \\
\hline \multicolumn{5}{|l|}{ FRMSSA } \\
\hline Overall & FRMRSA/MRSA & 72 & $3211 / 50,078$ & $5.8(5.0-6.6)$ \\
\hline
\end{tabular}


Table 2 (continued)

\begin{tabular}{|c|c|c|c|c|}
\hline Category & Subcategory & No. studies & No. strains & Prevalence (\%) $(95 \% \mathrm{Cl})$ \\
\hline \multirow[t]{14}{*}{ Country } & Australia & 3 & $117 / 1470$ & $7.7(1.1-14.3)$ \\
\hline & Canada & 4 & 269/3477 & $6.4(4.1-8.8)$ \\
\hline & China & 3 & $4 / 126$ & $2.9(0.0-5.8)$ \\
\hline & France & 2 & $74 / 1437$ & $7.8(0.0-19.0)$ \\
\hline & Germany & 2 & $27 / 253$ & $10.3(6.5-14.0)$ \\
\hline & Iran & 3 & $10 / 253$ & $3.5(1.2-5.7)$ \\
\hline & Kuwait & 3 & $847 / 7002$ & $9.3(3.6-15.1)$ \\
\hline & Malaysia & 4 & $84 / 1642$ & $4.8(3.8-5.9)$ \\
\hline & Pakistan & 2 & $47 / 583$ & $6.6(4.6-8.6)$ \\
\hline & Serbia & 2 & $6 / 144$ & $3.6(0.6-6.7)$ \\
\hline & Taiwan & 3 & 99/716 & $8.6(0.4-16.7)$ \\
\hline & Turkey & 5 & 49/796 & $5.6(2.7-8.6)$ \\
\hline & UK & 16 & $1374 / 27,138$ & $5.1(4.1-6.1)$ \\
\hline & USA & 3 & $26 / 653$ & $3.7(2.3-5.2)$ \\
\hline \multicolumn{5}{|l|}{ FRMSSA } \\
\hline Overall & FRMSSA/S. aureus & 9 & $939 / 11,992$ & $6.7(5.4-7.9)$ \\
\hline Country & UK & 4 & $906 / 11,265$ & $8.0(7.3-8.8)$ \\
\hline Overall & FRMSSA/MSSA & 42 & $2437 / 70,438$ & $3.0(2.6-3.5)$ \\
\hline \multirow[t]{7}{*}{ Country } & Australia & 2 & $60 / 1734$ & $3.4(2.6-4.3)$ \\
\hline & Canada & 2 & $62 / 2178$ & $3.6(0.6-6.6)$ \\
\hline & China & 3 & $37 / 2203$ & $1.5(1.0-2.1)$ \\
\hline & Germany & 3 & $22 / 674$ & $2.9(1.7-4.2)$ \\
\hline & Malaysia & 2 & $10 / 348$ & $2.2(0.0-5.1)$ \\
\hline & Turkey & 4 & $10 / 382$ & $1.8(0.5-3.1)$ \\
\hline & UK & 13 & $2184 / 61,050$ & $3.5(2.8-4.2)$ \\
\hline
\end{tabular}

and $3.2 \%$ (95\% CI 2.3-4.1) of 552/13,582 MRSA isolates in 2010-2020, respectively. The changes in FRSA, and FRMRSA prevalence and also the changes in FRMSSA prevalence in all three periods are shown in Tables 1 and 2.

\section{The prevalence of FRSA, FRMRSA and FRMSSA in different regions of the world}

Prevalence of FRSA, FRMRSA, and FRMSSA based on geographic area in the subgroup analysis are shown in Tables 1 and 2. As can be seen, the frequency of FRSA in Asia [5.6\% (95\% CI 4.6-6.6)] is 1.20 and 1.12-fold higher than in Europe [4.7\% (95\% CI 4.3-5.2)] or Oceania [5.0\% (95\% CI 3.7-6.3)], respectively. The prevalence of FRSA is almost the same in Asia, America, and Africa. Also, the frequency of FRMRSA in Asia [3.0\% (95\% CI 2.1-4.10)] is 1.57 and 2.72-fold higher than in Europe [1.9\% (95\% CI 1.5-2.2)] and Oceania [1.1\% (95\% CI 0.8-1.5)], respectively. It is noteworthy that the prevalence of FRMRSA in
Africa [6.8\% (95\% CI 3.6-9.9)] and America [4.3\% (95\% CI 1.5-7.2)] is higher than for other continents.

\section{Discussion}

The emergence of resistance to FA among S. aureus isolates has become a matter of concern in many different countries which makes it a threat to public health [153]. According to the evidence, the prevalence rate of FRSA strains differs in various geographic regions and/or patients population. In this systematic review, we noted a low prevalence of resistance to FA in $0.5 \%$ [(95\% CI) 4.6-5.4] of $S$. aureus isolates reflecting improved infection control precautions and effectiveness of continued surveillance of $S$. aureus infections [14, 153, 234]. The present systematic review illustrated a higher prevalence of FRSA in Asia (5.6\%) as compared to other continents. This is of serious concern reflecting inappropriate unrestricted policies and use of FA would similarly be higher in Asian countries $[235,236]$. This phenomenon is related 
to easy access to antibiotics without prescription, paucity of suitable alternatives to FA for topical administration and cheap antibiotics, in these areas [153, 235]. Although it is difficult to recommend completely outlawing use of FA, restricted use of this antibiotic in both community and health care settings and in combination with other antibiotics is highly recommended [234, 237]. It is worth noting that the incidence rate of FRSA strains gradually increased from $4.0 \%$ before 2000 to $5.2 \%$ in $2010-2020$. It seems that this increasing rate is directly linked to the increase in $S$. aureus infections and a shift in antibiotic pressures [14]. The present analyses exhibited a higher prevalence of FRMRSA (5.8\%) compared to FRMSSA (3.0\%). It is well-documented that MRSA isolates exhibited a high prevalence of multi-resistance towards antibiotics of different classes compare to MSSA strains which could limit the choices available for the control of MRSA infections. However, the use of FA outside the hospital is still not justified [236-238]. Furthermore, clinician' and patient' education is an important aspect promoting the appropriate use and prescription of FA together with close monitoring of antibiotic susceptibility patterns and use of this antibiotic in combination with other drugs to prevent further emergence of these strains. However, our analysis suggests that both MRSA and MSSA strains must be evaluated routinely in terms of resistance to FA. The current systematic review illustrated a high prevalence of FRMRSA in Africa (6.8\%) and America (4.3\%) compared to other continents. Although there is wide diversity among MRSA molecular types colonizing and infecting the population in different parts of the world, the higher relative prevalence of FRMRSA highlight the need for clinician's awareness in administration and use of FA in community and hospital setting in Africa and America. It is well known that too many prescription guidelines are according to the outmoded data gained from observational studies of a small size. Also, it must be borne in mind that there is limited understanding of FA resistance at the epidemiological, clinical, and genetic level [239-241]. Moreover, infection control efforts as a main framework and strategy are crucial to decline the emergence and prevalence of FRMRSA strains [14, 237, 240]. One potential explanation for the higher prevalence of FRMRSA in America (4.3\%) could be related to phenotypic methods used and breakpoint values applied for the screening and detection of FRMRSA. There were some drawbacks in the current review. Only published scientific studies were considered for the present metaanalysis and potential publication bias had to be considered. Secondly, we aimed to investigate the prevalence of FRSA, FRMRSA, and FRMSSA in all countries. Since many countries had no record of the prevalence of these strains, we were not able to reach this goal. The prevalence of rampant bacteria in patients with $S$. aureus infection disease is not well established in many countries. So, the prevalence of these FRSA, FRMRSA, and FRMSSA in patients with $S$. aureus infection should be investigated in every country to gather comprehensive information.

\section{Conclusion}

This meta-analysis depicted trends towards an increasing incidence of FRSA, FRMSSA, and FRMRSA. The findings highlight the need for the implementation of (ongoing) surveillance, antibiotic stewardship measures to mitigate the emergence and spread of FRSA, gathering epidemiological data to understand the peculiarities of the epidemiology, medical burden and risk factors related to FRSA, harmonized guidelines for infection control, education of clinicians on the proper prescribing of FA, and development of strategies for monitoring the effects of FA use.

\section{Supplementary Information}

The online version contains supplementary material available at https://doi. org/10.1186/s13756-021-00943-6.

Additional file 1: Tables S1-S3. Characteristics of included studies.

\section{Acknowledgements}

The authors would like to thank Dr. Ali Hashemi, Department of Microbiology at Shahid Beheshti University of Medical Sciences, Tehran, Iran, for his sincere assistance and efforts to make this project happen.

\section{Authors' contributions}

$\mathrm{MD}$ and $\mathrm{BH}$, designed the study. $\mathrm{BH}$ and $\mathrm{HG}$ conducted the search strategy. $\mathrm{BH}, \mathrm{SK}, \mathrm{SA}$ and $\mathrm{SZ}$ performed the data extraction. $\mathrm{MD}, \mathrm{BH}$ and $\mathrm{MG}$, wrote and edited the manuscript. MD carried out the statistical analysis. MD, HG and AVB assumed overall responsibility for the accuracy and integrity of the manuscript. All authors read and approved the final manuscript.

\section{Funding}

The present study was financially supported by grant 4008 from the Alborz University of Medical Sciences, Karaj, Iran.

\section{Declarations}

Ethical approval and consent to participate. Not required.

\section{Competing interests}

AVB is an employee of bioMérieux, a French company developing diagnostic tools for infectious diseases. The company has had no influence on the design and execution of the current study. No competing interests apply for the other authors. 


\begin{abstract}
Author details
${ }^{1}$ Department of Microbiology, School of Medicine, Shahid Beheshti University of Medical Sciences, Tehran, Iran. ${ }^{2}$ Data Analytics Unit, bioMérieux 3, Route de Port Michaud, La Balme Les Grottes, France. ${ }^{3}$ Department of Microbiology, School of Medicine, Alborz University of Medical Sciences, Karaj, Iran. ${ }^{4}$ Non-Communicable Diseases Research Center, Alborz University of Medical Sciences, Karaj, Iran.
\end{abstract}

Received: 21 January 2021 Accepted: 23 April 2021 Published online: 01 May 2021

\section{References}

1. Gordon RJ, Lowy FD. Pathogenesis of methicillin-resistant Staphylococcus aureus infection. Clin Infect Dis. 2008:46(5):S350-9.

2. Armin S, Fareghi F, Fallah F, Dadashi M, Nikmanesh B, Ghalavand Z. Prevalence of hlg and pvl genes in methicillin resistant Staphylococcus aureus (MRSA) isolated from health care staff in Mofid Children Hospital, Tehran. Iran J Pure Appl Microbiol. 2015:9(2):1001-5.

3. Razavi S, Dadashi M, Pormohammad A, Khoramrooz SS, Mirzaii M, Gholipour A, et al. Methicillin-resistant staphylococcus epidermidis in Iran: a systematic review and meta-analysis. Arch Clin Infect Dis. 2018:13(4):e58410.

4. Foster TJ. Antibiotic resistance in Staphylococcus aureus. Current status and future prospects. FEMS Microbiol Rev. 2017:41(3):430-49.

5. Dadashi M, Hajikhani B, Darban-Sarokhalil D, van Belkum A, Goudarzi M Mupirocin resistance in Staphylococcus aureus: a systematic review and meta-analysis. J Glob Antimicrob Resist. 2020:20:238-47.

6. Hasani A, Purmohammad A, Rezaee MA, Hasani A, Dadashi M. Integronmediated multidrug and quinolone resistance in extended-spectrum Blactamase-producing Escherichia coli and Klebsiella pneumoniae. 2017; 5:e36616.

7. Wu P-P, He H, Hong WD, Wu T-R, Huang G-Y, Zhong Y-Y, et al. The biological evaluation of fusidic acid and its hydrogenation derivative as antimicrobial and anti-inflammatory agents. Infect Drug Resist. 2018;11:1945s.

8. Turnidge J. Fusidic acid pharmacology, pharmacokinetics and pharmacodynamics. Int J Antimicrob Agents. 1999;12(Suppl 2):S23-34.

9. Wilkinson JD. Fusidic acid in dermatology. Br J Dermatol. 1998;139(Suppl 53):37-40

10. Curbete MM, Salgado HR. A critical review of the properties of fusidic acid and analytical methods for its determination. Crit Rev Anal Chem. 2016:46(4):352-60.

11. O'Neill AJ, Chopra I. Molecular basis of fusB-mediated resistance to fusidic acid in Staphylococcus aureus. Mol Microbiol. 2006:59(2):664-76.

12. McLaws FB, Larsen AR, Skov RL, Chopra I, O'Neill AJ. Distribution of fusidic acid resistance determinants in methicillin-resistant Staphylococcus aureus. Antimicrob Agents Chemother. 2011;55(3):1173-6.

13. O'Neill AJ, McLaws F, Kahlmeter G, Henriksen AS, Chopra I. Genetic basis of resistance to fusidic acid in staphylococci. Antimicrob Agents Chemother. 2007;51(5):1737-40

14. Castanheira M, Watters AA, Mendes RE, Farrell DJ, Jones RN. Occurrence and molecular characterization of fusidic acid resistance mechanisms among Staphylococcus spp. from European countries (2008). J Antimicrob Chemother. 2010;65(7):1353-8.

15. CLSI. Performance Standards for Antimicrobial Susceptibility Testing 30th ed. CLSI supplement M100. Wayne P. Clinical and Laboratory Standards Institute. 2020

16. Institute TJB. Joanna Briggs Institute Reviewers' Manual. 2014th ed. Adelaide: Joanna Briggs Institute; 2014.

17. Mantel N, Haenszel W. Statistical aspects of the analysis of data from retrospective studies of disease. J Natl Cancer Inst. 1959;22(4):719-48.

18. DerSimonian R, Laird N. Meta-analysis in clinical trials. Control Clin Trials. 1986;7(3):177-88

19. Higgins J, Thompson SG. Quantifying heterogeneity in a meta-analysis. Stat Med. 2002;21(11):1539-58.

20. Rohani MY, Raudzah A, Lau MG, Zaidatul AAR, Salbiah MN, Keah KC et al. Susceptibility pattern of Staphylococcus aureus isolated in Malaysian hospitals. Int J Antimicrob Agents. 2000;13(3):209-13 (in English)
21. Wiśniewska K, Piechowicz L, Galiński J. Predominance of multidrug resistant strains with reduced susceptibility to fusidic acid among methicillin-resistant Staphylococcus aureus strains (MRSA) isolated in the Gdánsk region. Polski merkuriusz lekarski: organ Polskiego Towarzystwa Lekarskiego. 2000;9(53):746-50 (in Polish).

22. Atmaca S, Özekinci T, Özerdem N. Fusidic acid susceptibilities of methicillin-sensitive and methicillin-resistant Staphylococcus aureus strains. Mikrobiyoloji Bulteni. 2001;35(1):25-8 (in Turkish).

23. Belabbes H, Elmdaghri N, Hachimi K, Marih L, Zerouali K, Benbachir M. Antibiotic resistance of Staphylococcus aureus isolated from community and nosocomial infections in Casablanca. Med Maladies Infect. 2001;31(1):25-8.

24. Gosbell IB, Mercer JL, Neville SA, Chant KG, Munro R. Communityacquired, non-multiresistant oxacillin-resistant Staphylococcus aureus (NORSA) in South Western Sydney. Pathology. 2001;33(2):206-10.

25. Quentin C, Grobost F, Fischer I, Dutilh B, Brochet JP, Jullin J, et al. Antibiotic resistance of Staphylococcus aureus in extra-hospital practice: a six-month period study in aquitaine. Pathol Biol (Paris). 2001;49(1):33-40 (in French).

26. Schaefer F, Bruttin O, Zografos L, Guex-Crosier Y. Bacterial keratitis: a prospective clinical and microbiological study. Br J Ophthalmol. 2001;85(7):842-7.

27. Tunger O, Arisoy A, Kurutepe S, Akcali S, Ozbakkaloglu B. In vitro susceptibility of Staphylococcus aureus and coagulase-negative Staphylococcus strains to fusidic acid. Int J Antimicrob Agents. 2001;18(5):445-7.

28. Arkwright PD, Daniel TO, Sanyal D, David TJ, Patel L. Age-related prevalence and antibiotic resistance of pathogenic staphylococci and streptococci in children with infected atopic dermatitis at a single-specialty center. Arch Dermatol. 2002;138(7):939-41.

29. Brown EM, Thomas P. Fusidic acid resistance in Staphylococcus aureus isolates. Lancet (London, England). 2002;359(9308):803.

30. Hwang JH, Chu CK, Liu TC. Changes in bacteriology of discharging ears. J Laryngol Otol. 2002;116(9):686-9.

31. Hwang JH, Tsai HY, Liu TC. Community-acquired methicillin-resistant Staphylococcus aureus infections in discharging ears. Acta Otolaryngol. 2002;122(8):827-30.

32. Livermore D, James D, Duckworth G, Stephens P. Fusidic-acid use and resistance. Lancet (London, England). 2002;360(9335):806.

33. Memikoğlu KO, Bayar B, Kurt Ö, Çokça F. In-vitro susceptibility of methicillin resistant Staphylococcus aureus to fusidic acid and trimethoprim - Sulfamethoxazole. Mikrobiyoloji Bulteni. 2002;36(2):141-5 (in Turkish).

34. Nishijima S, Kurokawa I. Antimicrobial resistance of Staphylococcus aureus isolated from skin infections. Int J Antimicrob Agents. 2002;19(3):241-3.

35. Norazah A, Lim VKE, Koh YT, Rohani MY, Zuridah H, Spencer K, et al. Molecular fingerprinting of fusidic acid-and rifampicin-resistant strains of methicillin-resistant Staphylococcus aureus (MRSA) from Malaysian hospitals. J Med Microbiol. 2002;51(12):1113-6 (in English).

36. Osterlund A, Eden T, Olsson-Liljequist B, Haeggman S, Kahlmeter G, Swedish Study Grp Fusid A-R. Clonal spread among Swedish children of a Staphylococcus aureus strain resistant to fusidic acid. Scand J Infect Dis. 2002;34(10):729-34.

37. Sule O, Brown N, Brown DFJ, Burrows N. Fusidic acid cream for impetigo-Judicious use is advisable. BMJ. 2002;324(7350):1394-5.

38. Wiśniewska K, Dajnowska-Stanczewa A, Galiński J, Garbacz K. Methicillin-resistant Staphylococcus aureus (MRSA) with high resistance to mupirocin in hospitals of the Gdańsk region. Medycyna doświadczalna i mikrobiologia. 2002;54(4):285-92 (in Polish).

39. Grohs P, Kitzis MD, Gutmann L. In vitro bactericidal activities of linezolid in combination with vancomycin, gentamicin, ciprofloxacin, fusidic acid, and rifampin against Staphylococcus aureus. Antimicrob Agents Chemother. 2003:47(1):418-20.

40. Kesah C, Ben Redjeb S, Odugbemi TO, Boye CS, Dosso M, Ndinya Achola $\mathrm{JO}$, et al. Prevalence of methicillin-resistant Staphylococcus aureus in eight African hospitals and Malta. Clin Microbiol Infect. 2003;9(2):153-6.

41. Lorette G, Beaulieu P, Bismuth R, Duru G, Guihard W, Lemaitre M, et al. Community-acquired cutaneous infections: causal role of some bacteria and sensitivity to antibiotics. Ann Dermatol Venereol. 2003;130(8-9 1):723-8 (in French). 
42. Norazah A, Lim VK, Munirah SN, Kamel AG. Staphylococcus aureus carriage in selected communities and their antibiotic susceptibility patterns. Med J Malays. 2003;58(2):255-61.

43. Rørtveit S, Rørtveit $\mathrm{G}$. An epidemic of bullous impetigo in an island community in Norway in the year 2002. Tidsskr Nor Laegeforen. 2003;123(18):2557-60 (in Norwegian)

44. Shah M, Mohanraj M. High levels of fusidic acid-resistant Staphylococcus aureus in dermatology patients. Br J Dermatol. 2003;148(5):1018-20.

45. Tveten $Y$, Jenkins A, Allum AG, Kristiansen BE, Norwegian MSG. Heterogeneity of methicillin-resistant Staphylococcus aureus isolated in Norway. Clin Microbiol Infect. 2003;9(8):886-92.

46. Akpabie A, Naga H, Giraud K, Al Rahiss R, Nadai S. Resistance to linezolid in Staphylococcus aureus before its release. Parodontol. 2004;52(8):493-6.

47. Cartolano GL, Cheron M, Benabid D, Leneveu M, Boisivon A, Marchal MF, et al. Methicillin-resistant Staphylococcus aureus (MRSA) with reduced susceptibility to glycopeptides (GISA) in 63 French general hospitals. Clin Microbiol Infect. 2004;10(5):448-51 (in English).

48. El-Zimaity D, Kearns AM, Dawson SJ, Price S, Harrison GAJ. Survey, characterization and susceptibility to fusidic acid of Staphylococcus aureus in the Carmarthen area. J Antimicrob Chemother. 2004;54(2):441-6 (in English).

49. Erdenizmenli M, Yapar N, Sengonul A, Yuce A, Cakir N, Yulug N. In-vitro activity of fusidic acid against methicillin-resistant Staphylococcus aureus. Journal of chemotherapy (Florence, Italy). 2004;16(3):310-1.

50. Hoeger PH. Antimicrobial susceptibility of skin-colonizing S. aureus strains in children with atopic dermatitis. Pediatr Allergy Immunol. 2004;15(5):474-7

51. Lescat M, Dupeyron C, Faubert E, Mangeney N. Pulse-field gel electrophoresis typing of methicillin-resistant Staphylococcus aureus strains susceptible to aminoglycosides isolated from 1993 to 2002. J Hosp Infect. 2004;57(3):253-7.

52. Lindberg E, Adlerberth I, Wold AE. Antibiotic resistance in Staphylococ cus aureus colonising the intestines of Swedish infants. Clin Microbiol Infect. 2004;10(10):890-4.

53. Morrissey I, Burnett R, Viljoen L, Robbins M. Surveillance of the susceptibility of ocular bacterial pathogens to the fluoroquinolone gatifloxacin and other antimicrobials in Europe during 2001/2002. J Infect. 2004;49(2):109-14.

54. Seydi M, Sow Al, Soumaré M, Diallo HM, Hatim B, Tine R, et al. Staphylococcus aureus bacteremia in the Dakar Fann university hospital. Med Maladies Infect. 2004;34(5):210-5 (in French).

55. Zinn CS, Westh H, RosdahI VT. An international multicenter study of antimicrobial resistance and typing of hospital Staphylococcus aureus isolates from 21 laboratories in 19 countries or states. Microb Drug Resist. 2004:10(2):160-8.

56. Al Sweih N, Mokaddas E, Jamal W, Phillips OA, Rotimi VO. In vitro activity of linezolid and other antibiotics against Gram-positive bacteria from the major teaching hospitals in Kuwait. Journal of chemotherapy (Florence, Italy). 2005;17(6):607-13.

57. Denis O, Deplano A, De Beenhouwer H, Hallin M, Huysmans G, Garrino $M G$, et al. Polyclonal emergence and importation of communityacquired methicillin-resistant Staphylococcus aureus strains harbouring Panton-Valentine leucocidin genes in Belgium. J Antimicrob Chemother. 2005;56(6):1103-6.

58. Gilani SJK, Gonzalez M, Hussain I, Finlay AY, Patel GK. Staphylococcus aureus re-colonization in atopic dermatitis: beyond the skin. Clin Exp Dermatol. 2005:30(1):10-3.

59. Norazah A, Lim VK, Rohani MY, Kamel AG. In-vitro activity of quinupristin/dalfopristin, levofloxacin and moxifloxacin against fusidic acid and rifampicin-resistant strains of methicillin-resistant Staphylococcus aureus (MRSA) from Malaysian hospitals. Med J Malays. 2005;60(4):411-5.

60. Samra Z, Ofer O, Shmuely H. Susceptibility of methicillin-resistant Staphylococcus aureus to vancomycin, teicoplanin, linezolid, pristinamycin and other antibiotics. Isr Med Assoc J. 2005;7(3):148-50.

61. Vourli S, Perimeni D, Makri A, Polemis M, Voyiatzi A, Vatopoulos A. Community acquired MRSA infections in a paediatric population in Greece. Euro surveillance: bulletin Europeen sur les maladies transmissibles $=$ Eur Commun Dis Bull. 2005;10(5):78-9.
62. Kareiviene V, Pavilonis A, Sinkute G, Liegiute S, Gailiene G. Staphylococcus aureus resistance to antibiotics and spread of phage types. Medicina (Kaunas). 2006:42(4):332-9.

63. Kim MS, Chung BS, Choi KC. A study of antibiotic susceptibility of Staphylococcus aureus in bacterial skin infections. Korean J Dermatol. 2006;44(7):805-10 (in Korean).

64. Koning S, Mohammedamin RSA, Van Der Wouden JC, Van SuijlekomSmit LWA, Schellevis FG, Thomas S. Impetigo: Incidence and treatment in Dutch general practice in 1987 and 2001_results from two national surveys. Br J Dermatol. 2006;154(2):239-43 (in English).

65. Rennie RP. Susceptibility of Staphylococcus aureus to fusidic acid: Canadian data. J Cutan Med Surg. 2006;10(6):277-80.

66. Saginur R, Stdenis M, Ferris W, Aaron SD, Chan F, Lee C, et al. Multiple combination bactericidal testing of staphylococcal biofilms from implant-associated infections. Antimicrob Agents Chemother. 2006:50(1):55-61.

67. Stevens CL, Ralph A, McLeod JE, McDonald MI. Community-acquired methicillin-resistant Staphylococcus aureus in Central Australia. Commun Dis Intell Q Rep. 2006;30(4):462-6.

68. Udo EE, Al-Sweih N, Mohanakrishnan S, West PW. Antibacterial resistance and molecular typing of methicillin-resistant Staphylococcus aureus in a Kuwaiti general hospital. Med Princip Pract Int J Kuwait Univ Health Sci Centre. 2006;15(1):39-45

69. Udo EE, Al-Sweih N, Mokaddas E, Johny M, Dhar R, Gomaa HH, et al. Antibacterial resistance and their genetic location in MRSA isolated in Kuwait hospitals, 1994-2004. BMC Infect Dis. 2006;6:168.

70. Abdallah M, Zaki SM, El-Sayed A, Erfan D. Evaluation of secondary bacterial infection of skin diseases in Egyptian in-and out-patients and their sensitivity to antimicrobials. Egypt Dermatol Online J. 2007:3:1-15.

71. Jorgen B, Merckoll P, Melby KK. Susceptibility to daptomycin, quinupristin-dalfopristin and linezolid and some other antibiotics in clinical isolates of methicillin resistant and methicillin sensitive $S$. aureus from the Oslo area. Scand J Infect Dis. 2007;39(11-12):1059-62.

72. Perwaiz S, Barakzi Q, Farooqi BJ, Khursheed N, Sabir N. Antimicrobial susceptibility pattern of clinical isolates of methicillin resistant Staphylococcus aureus. JPMA J Pak Med Assoc. 2007:57(1):2-4.

73. Randrianirina F, Soares JL, Ratsima E, Carod JF, Combe P, Grosjean P, et al. In vitro activities of 18 antimicrobial agents against Staphylococcus aureus isolates from the Institut Pasteur of Madagascar. Ann Clin Microbiol Antimicrob. 2007;6:5.

74. Bernard P, Jarlier V, Santerre-Henriksen A. Antibiotic susceptibility of Staphylococcus aureus strains responsible for cutaneous infections in the community. Ann Dermatol Venereol. 2008;135(1):13-9 (in French).

75. Cercenado E, Cuevas O, Marin M, Bouza E, Trincado P, Boquete T, et al. Community-acquired methicillin-resistant Staphylococcus aureus in Madrid, Spain: transcontinental importation and polyclonal emergence of Panton-Valentine leukocidin-positive isolates. Diagn Microbiol Infect Dis. 2008;61(2):143-9.

76. Denton M, O'Connell B, Bernard P, Jarlier V, Williams Z, Henriksen AS. The EPISA study: antimicrobial susceptibility of Staphylococcus aureus causing primary or secondary skin and soft tissue infections in the community in France, the UK and Ireland. J Antimicrob Chemother. 2008:61(3):586-8.

77. Gubbay JB, Gosbell IB, Barbagiannakos T, Vickery AM, Mercer JL, Watson M. Clinical features, epidemiology, antimicrobial resistance, and exotoxin genes (including that of Panton-Valentine leukocidin) of gentamicin-susceptible methicillin-resistant Staphylococcus aureus (GSMRSA) isolated at a paediatric teaching hospital in New South Wales, Australia. Pathology. 2008;40(1):64-71.

78. Jappe U, Heuck D, Strommenger B, Wendt C, Werner G, Altmann D, et al. Staphylococcus aureus in dermatology outpatients with special emphasis on community-associated methicillin-resistant strains. Invest Dermatol. 2008;128(11):2655-64.

79. Kedzierska A, Kapinska-Mrowiecka M, Czubak-Macugowska M, Wojcik K, Kedzierska J. Susceptibility testing and resistance phenotype detection in Staphylococcus aureus strains isolated from patients with atopic dermatitis, with apparent and recurrent skin colonization. Br J Dermatol. 2008;159(6):1290-9.

80. Larsen AR, Bocher S, Stegger A, Goering R, Pallesen LV, Skov R. Epidemiology of European community-associated methicillin-resistant 
Staphylococcus aureus clonal complex 80 type IV strains isolated in Denmark from 1993 to 2004. J Clin Microbiol. 2008;46(1):62-8

81. Niebuhr M, Mai U, Kapp A, Werfel T. Antibiotic treatment of cutaneous infections with Staphylococcus aureus in patients with atopic dermatitis: current antimicrobial resistances and susceptibilities. Exp Dermatol. 2008;17(11):953-7.

82. Udo EE, Al-Sweih N, Dhar R, Dimitrov TS, Mokaddas EM, Johny M, et al. Surveillance of antibacterial resistance in Staphylococcus aureus isolated in Kuwaiti hospitals. Med Princip Pract Int J Kuwait Univ Health Sci Centre. 2008;17(1):71-5.

83. Udo EE, Panigrahi D, Jamsheer AE. Molecular typing of methicillin-resistant Staphylococcus aureus isolated in a Bahrain hospital. Med Princip Pract Int J Kuwait Univ Health Sci Centre. 2008;17(4):308-14.

84. Woodford N, Afzal-Shah M, Warner M, Livermore DM. In vitro activity of retapamulin against Staphylococcus aureus isolates resistant to fusidic acid and mupirocin. J Antimicrob Chemother. 2008;62(4):766-8.

85. Bauer CC, Apfalter P, Daxboeck F, Bachhofner N, Stadler M, Blacky A, et al. Prevalence of panton-valentine leukocidin genes in methicillinresistant staphylococcus aureus isolates phenotypically consistent with community-acquired MRSA, 1999-2007, vienna general hospital. Eur J Clin Microbiol Infect Dis. 2009;28(8):909-12 (in English).

86. Brosnikoff C, Rennie R, Kidson P, Yamamura D, Bechard C, Kelly M, et al. Surveillance of staphylococcus aureus susceptibility to fusidic acid in five Canadian laboratories. Int J Antimicrob Agents. 2009;34:S43 (in English).

87. Claesson C, Nilsson LE, Kronvall G, Walder M, Sorberg M. Antimicrobial activity of tigecycline and comparative agents against clinical isolates of staphylococci and enterococci from ICUs and general hospital wards at three Swedish university hospitals. Scand I Infect Dis. 2009:41(3):171-81.

88. Idrees F, Jabeen K, Khan MS, Zafar A. Antimicrobial resistance profile of methicillin resistant Staphylococcal aureus from skin and soft tissue isolates. JPMA J Pak Med Assoc. 2009;59(5):266-9.

89. Kim SM, Lee DC, Park SD, Kim BS, Kim JK, Choi MR, et al. Genotype, coagulase type and antimicrobial susceptibility of methicillin-resistant Staphylococcus aureus isolated from dermatology patients and healthy individuals in Korea. J Bacteriol Virol. 2009;39(4):307-16 (in Korean)

90. Laurent F, Tristan A, Croze M, Bes M, Meugnier H, Lina G, et al. Presence of the epidemic European fusidic acid-resistant impetigo clone (EEFIC) of Staphylococcus aureus in France. J Antimicrob Chemother. 2009;63(2):420-1.

91. Mitra A, Mohanraj M, Shah M. High levels of fusidic acid-resistant Staphylococcus aureus despite restrictions on antibiotic use. Clin Exp Dermatol. 2009;34(2):136-9.

92. Nickerson EK, Hongsuwan M, Limmathurotsakul D, Wuthiekanun V, Shah KR, Srisomang P, et al. Staphylococcus aureus bacteraemia in a tropical setting: patient outcome and impact of antibiotic resistance. PLOS ONE. 2009;4(1):e4308.

93. Scangarella-Oman NE, Shawar RM, Bouchillon S, Hoban D. Microbiological profile of a new topical antibacterial: retapamulin ointment $1 \%$. Expert Rev Anti Infect Ther. 2009;7(3):269-79.

94. Scicluna EA, Shore A, Thürmer A, Slickers P, Ehricht R, Borg MA, et al. Molecular epidemiology of MRSA in Malta and the description of a Maltese epidemic MRSA strain. Int J Med Microbiol. 2009;299:40-1 (in English).

95. Uluğ M, Ayaz C, Çelen MK. The importance of fusidic acid in the treatment of chronic osteomyelitis. Anatol J Clin Investig. 2009;3(4):222-6 (in Turkish).

96. Willey B, Gnanasuntharam P, Rostas A, Porter V, Kreiswirth N, Louie L, et al. Molecular diversity of community-acquired Methicillin-Resistant Staphylococcus Aureus (MRSA) in Toronto. Int J Antimicrob Agents. 2009;34:S110-1 (in English)

97. Alsterholm M, Flytstrom I, Bergbrant IM, Faergemann J. Fusidic acidresistant Staphylococcus aureus in impetigo contagiosa and secondarily infected atopic dermatitis. Acta Derm Venereol. 2010;90(1):52-7.

98. Castanheira M, Farrell D, Janechek M, Jones R. CEM-102 (fusidic acid) in vitro activity and evaluation of molecular resistance mechanisms among European Gram-positive isolates, 2008-2009. Clin Microbiol Infect. 2010;16:S247-8 (in English).

99. Castanheira M, Watters AA, Bell JM, Turnidge JD, Jones RN. Fusidic acid resistance rates and prevalence of resistance mechanisms among Staphylococcus spp. isolated in North America and Australia, 2007-2008. Antimicrob Agents Chemother. 2010;54(9):3614-7.

100. Chen HJ, Hung WC, Tseng SP, Tsai JC, Hsueh PR, Teng LJ. Fusidic acid resistance determinants in Staphylococcus aureus clinical isolates. Antimicrob Agents Chemother. 2010;54(12):4985-91.

101. Cirkovic I, Svabic Vlahovic M, Stepanovic S. Molecular characterization of Panton-Valentine leukocidin positive methicillin-resistant Staphylococcus aureus isolates in Serbia. Clin Microbiol Infect. 2010;16:S278 (in English).

102. Elazhari M, Zerouali K, Dersi N, Saile R, Timinouni M, Hassar M. Variability of fusidic acid-resistant methicillin-sensitive Staphylococcus aureus isolates in Casablanca. Morocco Clin Microbiol Infect. 2010;16:S281 (in English).

103. Jones RN, Castanheira M, Rhomberg PR, Woosley LN, Pfaller MA. Performance of fusidic acid (CEM-102) susceptibility testing reagents: Broth microdilution, disk diffusion, and Etest methods as applied to Staphylococcus aureus. J Clin Microbiol. 2010;48(3):972-6 (in English).

104. Pfaller MA, Castanheira M, Sader HS, Jones RN. Evaluation of the activity of fusidic acid tested against contemporary Gram-positive clinical isolates from the USA and Canada. Int J Antimicrob Agents. 2010;35(3):282-7 (in English)

105. Rijnders M, Nys S, Driessen C, Hoebe CJ, Hopstaken RM, Oudhuis GJ, et al. Staphylococcus aureus carriage among GPs in The Netherlands. Br J Gen Pract J R Coll Gen Pract. 2010;60(581):902-6.

106. Udo E, Sarkhoo E. The expansion of ST80-SCCmec-IV clone of communityacquired methicillin resistant Staphylococcus aureus in Kuwait hospitals. Int J Infect Dis. 2010;14:e345-6 (in English).

107. Udo EE, Sarkhoo E. The dissemination of ST80-SCCmec-IV communityassociated methicillin resistant Staphylococcus aureus clone in Kuwait hospitals. Ann Clin Microbiol Antimicrob. 2010;9:1-7 (in English).

108. Yeung CK, Chow WC, Chan HHL, Ho PL. Carriage of antibiotic-resistant Staphylococcus aureus in atopic dermatitis children attending paediatric outpatient clinics, Hong Kong. J Dermatol Venereol. 2010;18(3):125-31 (in English).

109. Alreshidi MA, Mariana NS. Increasing rate of detection of fusidic acid resistance in methicillin-resistant Staphylococcus aureus isolated from clinical samples in Malaysia. Med J Malays. 2011;66(3):276.

110. Anastasiou E, Farmaki EE, Pertsas E, Kakasi E, Koteli A. In vitro activity of fusidic acid against Staphylococcus aureus strains. Int J Infect Dis. 2011;15:S18 (in English).

111. Champion EA, Popowitch E, Miller M, Saiman L, Muhlebach M. MRSA: epidemiology, molecular typing and antimicrobial susceptibilities: multicenter STAR-CF study. Am J Respir Crit Care Med. 2011;183(1):A6120. (in English)

112. Chang $\mathrm{CH}$, Lin TC, Chang $\mathrm{CH}$, Hong SJ, Tsai YC. Methicillin-resistant Staphylococcus aureus in skin and soft tissue infections and minocyclin treatment experience in the dermatological setting of eastern Taiwan. Dermatol Sin. 2011;29(3):86-90 (in English)

113. Chen CM, Huang M, Chen HF, Ke SC, Li CR, Wang JH, et al. Fusidic acid resistance among clinical isolates of methicillin-resistant Staphylococcus aureus in a Taiwanese hospital. BMC Microbiol. 2011;11:98.

114. Jones RN, Mendes RE, Sader HS, Castanheira M. In vitro antimicrobial findings for fusidic acid tested against contemporary (2008-2009) gram-positive organisms collected in the United States. Clin Infect Dis. 2011;52(Suppl 7):S477-86

115. Lemaire S, Piérard D, Van Bambeke F, Tulkens P. Intracellular activity of fusidic acid against clinical isolates of Staphylococcus aureus of increasing MIC. Clin Microbiol Infect. 2011;17:S182-3 (in English).

116. Rørtveit S, Skutlaberg DH, Langeland N, Rortveit G. Impetigo in a population over 8.5 years: incidence, fusidic acid resistance and molecular characteristics. J Antimicrob Chemother. 2011;66(6):1360-4 (in English).

117. Titov L, Ermakova T, Gorbunov V, Lebedev F, Kazakov I, Glazkova S. Methicillin-resistant staphylococci in the Republic of Belarus: results of the National Surveillance System (2008-2010). Clin Microbiol Infect. 2011;17:S198-9 (in English).

118. Baek YS, Song HJ. Fusidic acid and mupirocin resistance of Staphylococcus aureus isolated from infected skin wounds of Korean patients. J Dermatol. 2012;39:21-2 (in English).

119. Berktold M, Grif K, Maser M, Witte W, Wurzner R, Orth-Holler D. Genetic characterization of Panton-Valentine leukocidin-producing 
methicillin-resistant Staphylococcus aureus in Western Austria. Wien Klin Wochenschr. 2012;124(19-20):709-15.

120. Chen X, Yang HH, Huangfu YC, Wang WK, Liu Y, Ni YX, et al. Molecular epidemiologic analysis of Staphylococcus aureus isolated from four burn centers. Burns. 2012;38(5):738-42 (in English).

121. Demir T, Coplu N, Bayrak H, Turan M, Buyukguclu T, Aksu N, et al. Panton-Valentine leucocidin gene carriage among Staphylococcus aureus strains recovered from skin and soft tissue infections in Turkey. J Antimicrob Chemother. 2012;67(4):837-40.

122. Groome MJ, Albrich WC, Wadula J, Khoosal M, Madhi SA. Communityonset Staphylococcus aureus bacteraemia in hospitalised African children: high incidence in HIV-infected children and high prevalence of multidrug resistance. Paediatr Int Child Health. 2012;32(3):140-6.

123. Horner C, Kearns A, Heritage J, Wilcox M. The epidemiology of methicillin-resistant Staphylococcus aureus in elderly residents of 65 care homes in a single primary care trust of northern England. Clin Microbiol Infect. 2012;18:341 (in English).

124. Ibrahim N, Siti-Fairuz MH, Nurul-Iwani MAA. A survey on community acquired-meticillin resistant Staphylococcus aureus burden among university students. Int J Infect Dis. 2012;16:e223 (in English).

125. Kunsang Bhutia O, Singh TSK. Occurrence and antimicrobial susceptibility pattern of community and hospital associated methicillin resistant staphylococcus aureus strains in Sikkim. J Int Med Sci Acad. 2012;25(4):235-7 (in English).

126. Nagarajan A, Arunkumar K, Saravanan M, Sivakumar G, Krishnan P. Detection of fusidic acid resistance determinants among Staphylococcus aureus isolates causing skin and soft tissue infections from a tertiary care centre in Chennai, South India. BMC Infect Dis. 2012;12:1 (in English).

127. Nergiz Ş, Atmaca S, Özekinci T, Tekin A. Fusidic acid resistance in staphylococcus aureus strains in an interval of ten years (2001-2011). Turk Klinikleri J Med Sci. 2012;32(6):1668-72 (in English).

128. Pichon B, Hill RLR, Blackburn R, Ganner M, Harwin L, Cookson B, et al. Molecular epidemiology of Staphylococcus aureus bacteraemia in the UK-2011. Clin Microbiol Infect. 2012;18:36 (in English).

129. Rashid Z, Sattar A, Qureshi MIM, Farzana K, Rashid F, Murtaza G. Nasal carriage of staphylococci in medical personnel, sanitary workers and non-medical personnel. Lat Am J Pharm. 2012;31(10):1496-500 (in English).

130. Sasirekha B, Usha MS, Amruta AJ, Ankit S, Brinda N, Divya R. Evaluation and comparison of different phenotypic tests to detect Methicillin resistant Staphylococcus aureus and their biofilm production. Int J PharmTech Res. 2012;4(2):532-41 (in English).

131. Shore AC, Brennan OM, Deasy EC, Rossney AS, Kinnevey PM, Ehricht $R$, et al. DNA microarray profiling of a diverse collection of nosocomial methicillin-resistant Staphylococcus aureus isolates assigns the majority to the correct sequence type and staphylococcal cassette chromosome mec (SCCmec) type and results in the subsequent identification and characterization of novel SCCmec-SCCM1 composite islands. Antimicrob Agents Chemother. 2012;56(10):5340-55 (in English)

132. Somily AM, Peaper DR, Paintsil E, Murray TS. Comparison of disk diffusion and Etest methods to determine the susceptibility of Staphylococcus aureus circulating in Riyadh, Saudi Arabia to fusidic acid. Int J Microbiol. 2012;2012:391251.

133. Strandén A, Frei R, Widmer AF. Lack of emergence of PVL-positive MRSA strains in a university hospital. Clin Microbiol Infect. 2012;18:339 (in English).

134. Udo E, Al-sweih N. Emergence and characterisation of communityassociated Methicillin-resistant Staphylococcus aureus at a neonatal special care unit. Int J Infect Dis. 2012;16:e387 (in English).

135. Ben Nejma M, Mastouri M, Bel Hadj Jrad B, Nour M. Characterization of Panton-Valentine leukocidin-positive community-acquired methicillinresistant Staphylococcus aureus clone in Tunisia. Diagn Microbiol Infect Dis. 2013;77(1):20-4 (in English)

136. Champion MD, Gray V, Eberhard C, Kumar S. The evolutionary history of amino acid variations mediating increased resistance of $S$. aureus identifies reversion mutations in metabolic regulators. PLOS ONE. 2013;8(2):e56466.

137. Chuamuangphan T, Chongtrakool P, Sungkanuparph S. Predicting factors of methicillin-resistant Staphylococcus aureus bacteremia among hospitalized patients in a tertiary-care hospital. Int J Antimicrob Agents. 2013;42:S147 (in English).

138. Coombs GW, Nimmo GR, Pearson JC, Collignon PJ, Bell JM, McLaws $\mathrm{ML}$, et al. Australian group on antimicrobial resistance hospital-onset Staphylococcus aureus Surveillance Programme annual report, 2011. Commun Dis Intell Q Rep. 2013;37(3):E210-8.

139. Dinić M, Vuković S, Kocić B, Dordević DS, Bogdanović M. Nasal carriage of Staphylococcus aureus in healthy adults and in school children. Acta Facultatis Medicae Naissensis. 2013;30(1):31-6 (in English)

140. Egyir B, Guardabassi L, Nielsen SS, Larsen J, Addo KK, Newman MJ, et al. Prevalence of nasal carriage and diversity of Staphylococcus aureus among inpatients and hospital staff at Korle Bu Teaching Hospital. Ghana J Glob Antimicrob Resist. 2013; 1(4):189-93 (in English).

141. Hasani A, Sheikhalizadeh V, Hasani A, Naghili B, Valizadeh V, Nikoonijad AR. Methicillin resistant and susceptible Staphylococcus aureus: appraising therapeutic approaches in the Northwest of Iran. Iran J Microbiol. 2013;5(1):56-62 (in English).

142. Heng YK, Tan KT, Sen P, Chow A, Leo YS, Lye DC, et al. Staphylococcus aureus and topical fusidic acid use: results of a clinical audit on antimicrobial resistance. Int J Dermatol. 2013;52(7):876-81 (in English).

143. Huang YC, Su LH, Lin TY. Nasal carriage of methicillin-resistant Staphylococcus aureus among pediatricians in Taiwan. PLOS ONE. 2013;8(11):e82472 (in English).

144. Lim KT, Abu Hanifah Y, Yus of MYM, Ito T, Thong KL. Comparison of methicillin-resistant Staphylococcus aureus strains isolated in 2003 and 2008 with an emergence of multidrug resistant ST22: SCCmec IV clone in a tertiary hospital, Malaysia. J Microbiol Immunol Infect. 2013;46(3):224-33.

145. Sahm DF, Deane J, Pillar CM, Fernandes P. In vitro activity of CEM102 (fusidic acid) against prevalent clones and resistant phenotypes of Staphylococcus aureus. Antimicrob Agents Chemother. 2013;57(9):4535-6.

146. Scerri J, Monecke S, Borg MA. Prevalence and characteristics of community carriage of methicillin-resistant staphylococcus aureus in malta. J Epidemiol Glob Health. 2013;3(3):165-73 (in English).

147. Sun M, Wang L, Liu Y, Li X, Sun J, Wang C, et al. Molecular characterization and antimicrobial resistance of community-associated methicillinresistant Staphylococcus aureus strains isolated from children with skin and soft tissue infections. Chin J Infect Chemother. 2013;13(1):19-24 (in English).

148. Treesirichod A, Hantagool S, Prommalikit O. Nasal carriage and antimicrobial susceptibility of Staphylococcus aureus among medical students at the HRH Princess Maha Chakri Sirindhorn Medical Center, Thailand: a cross sectional study. J Infect Public Health. 2013;6(3):196-201.

149. Tuncer Ertem G, Öztürk B, Ataman Hatlpoğlu C, Ipekkan K, Erdem F, Adiloğlu AK, et al. In vitro susceptibilities of staphylococcus and enterococcus isolates to linezolid, daptomycin, teicoplanin and fusidic acid. Turkiye Klinikleri J Med Sci. 2013;33(6):1381-7 (in English).

150. Udo EE, Al-Sweih N. Emergence of methicillin-resistant Staphylococcus aureus in the Maternity Hospital, Kuwait. Med Princip Pract Int J Kuwait Univ Health Sci Centre. 2013;22:535-9.

151. Ahmad B, Khan F, Ahmed J, Cha SB, Shin MK, Bashir S, et al. Antibiotic resistance pattern and molecular epidemiology of methicillin-resistant Staphylococcus aureus colonization in burns unit of a tertiary care hospital in Peshawar, Pakistan. Trop J Pharma Res. 2014;13(12):2091-9 (in English)

152. Akinkunmi EO, Adesunkanmi AR, Lamikanra A. Pattern of pathogens from surgical wound infections in a Nigerian hospital and their antimicrobial susceptibility profiles. Afr Health Sci. 2014;14(4):802-9.

153. den Heijer CD, van Bijnen EM, Paget WJ, Stobberingh EE. Fusidic acid resistance in Staphylococcus aureus nasal carriage strains in nine European countries. Future Microbiol. 2014;9(6):737-45.

154. Gordon NC, Price JR, Cole K, Everitt R, Morgan M, Finney J, et al. Prediction of Staphylococcus aureus antimicrobial resistance by wholegenome sequencing. J Clin Microbiol. 2014;52(4):1182-91.

155. Harastani HH, Tokajian ST. Community-associated methicillin-resistant Staphylococcus aureus clonal complex 80 type IV (CC80-MRSA-IV) isolated from the Middle East: a heterogeneous expanding clonal lineage. PLoS ONE. 2014;9(7):e103715.

156. Li J, Wang Q, Wang L, Sun M, Li S, Sun J, et al. Multidrug-resistant clones of methicillin-resistant Staphylococcus aureus isolated from Chinese 
children with community-associated pneumonia. Chin J Infect Chemother. 2014;14(1):32-7 (in Chinese).

157. Rortveit S, Skutlaberg DH, Langeland N, Rortveit G. The decline of the impetigo epidemic caused by the epidemic European fusidic acidresistant impetigo clone: an 11.5-year population-based incidence study from a community in Western Norway. Scand J Infect Dis. 2014;46(12):832-7.

158. Săndulescu O, Grigoraş A, Streinu-Cercel A, Berciu I, Neguț AC, StreinuCercel A. Resistance profile of Staphylococcus aureus strains isolated from patients treated in a tertiary care hospital in Romania. BMC Infect Dis. 2014;14(7):1-2 (in English).

159. Sfeir M, Obeid Y, Eid C, Saliby M, Farra A, Farhat H, et al. Prevalence of Staphylococcus aureus methicillin-sensitive and methicillin-resistant nasal and pharyngeal colonization in outpatients in Lebanon. Am J Infect Control. 2014;42(2):160-3.

160. Udo EE, Al-Lawati BAH, Al-Muharmi Z, Thukral SS. Genotyping of methicillin-resistant Staphylococcus aureus in the Sultan Qaboos University Hospital, Oman reveals the dominance of Panton-Valentine leucocidinnegative ST6-IV/t304 clone. New Microbes New Infect. 2014;2(4):100-5 (in English).

161. Vindel A, Trincado P, Cuevas O, Ballesteros C, Bouza E, Cercenado E. Molecular epidemiology of community-associated methicillin-resistant Staphylococcus aureus in Spain: 2004-12. J Antimicrob Chemother. 2014;69(11):2913-9 (in English).

162. Wasserman E, Orth H, Senekal M, Harvey K. High prevalence of mupirocin resistance associated with resistance to other antimicrobial agents in Staphylococcus aureus isolated from patients in private health care, Western Cape. Southern Afr J Epidemiol Infect. 2014;29(4):126-32 (in English).

163. Yildiz T, Çoban AY, Şener AG, Coşkuner SA, Bayramoğlu G, Güdücüoğlu $\mathrm{H}$, et al. Antimicrobial susceptibility and resistance mechanisms of methicillin resistant Staphylococcus aureus isolated from 12 Hospitals in Turkey. Ann Clin Microbiol Antimicrob. 2014;13(1):1-6 (in English).

164. Al-Talib H, Al-Khateeb A, Hassan H. Antimicrobial resistance of Staphylococcus aureus isolates in Malaysian tertiary hospital. Int Med J. 2015;22(2):73-5 (in English)

165. Aqel AA, Alzoubi HM, Vickers A, Pichon B, Kearns AM. Molecular epidemiology of nasal isolates of methicillin-resistant Staphylococcus aureus from Jordan. J Infect Public Health. 2015;8(1):90-7.

166. Bari F, Wazir R, Haroon M, Ali S, Imtiaz RH, et al. Frequency and antibiotic susceptibility profile of MRSA at lady reading hospital, Peshawar. Gomal J Med Sci. 2015;13(1):62-5.

167. Decousser JW, Desroches M, Bourgeois-Nicolaos N, Potier J, Jehl F, Lina $\mathrm{G}$, et al. Susceptibility trends including emergence of linezolid resistance among coagulase-negative staphylococci and meticillin-resistant Staphylococcus aureus from invasive infections. Int J Antimicrob Agents. 2015;46(6):622-30.

168. Ellington MJ, Reuter S, Harris SR, Holden MTG, Cartwright EJ, Greaves $\mathrm{D}$, et al. Emergent and evolving antimicrobial resistance cassettes in community-associated fusidic acid and meticillin-resistant Staphylococcus aureus. Int J Antimicrob Agents. 2015;45(5):477-84.

169. Park SH, Kim JK, Park K. In vitro antimicrobial activities of fusidic acid and retapamulin against mupirocin- and methicillin-resistant Staphylococcus aureus. Ann Dermatol. 2015;27(5):551-6.

170. Salah LA, Faergemann J. A retrospective analysis of skin bacterial colonisation, susceptibility and resistance in atopic dermatitis and impetigo patients. Acta Derm Venereol. 2015;95(5):532-5.

171. Vallières E, Rendall JC, Moore JE, McCaughan J, Tunney MM, Elborn JS, et al. MRSA eradication in CF patients with lower respiratory tract infection. J Cyst Fibros. 2015;14:S83 (in English).

172. Wang WY, Chiueh TS, Lee YT, Tsao SM. Correlation of molecular types with antimicrobial susceptibility profiles among 670 meca-positive MRSA isolates from sterile sites (tist study, 2006-2010). J Microbiol Immunol Infect. 2015;48(2):S39 (in English).

173. Yu FY, Liu YL, Lu CH, Lv JN, Qi XQ, Ding Y, et al. Dissemination of fusidic acid resistance among Staphylococcus aureus clinical isolates. BMC Microbiol. 2015;15:1-6.

174. Baek YS, Jeon J, Ahn JW, Song HJ. Antimicrobial resistance of Staphylococcus aureus isolated from skin infections and its implications in various clinical conditions in Korea. Int J Dermatol. 2016;55(4):e191-7.
175. Bessa GR, Machado DC, Weber MB, D'Azevedo PA, Quinto VP, Lipnharski C, et al. Staphylococcus aureus resistance to topical antimicrobials in atopic dermatitis. An Bras Dermatol. 2016;91(5):604-10 (in English).

176. Bhattacharya S, Pal K, Jain S, Chatterjee SS, Konar J. Surgical site infection by methicillin resistant Staphylococcus aureus-on decline. J Clin Diagn Res. 2016;10(9):DC32-6.

177. Bierowiec K, Ploneczka-Janeczko K, Rypula K. Is the colonisation of Staphylococcus aureus in pets associated with their close contact with owners? PLOS ONE. 2016;11(5):e0156052.

178. Boswihi SS, Udo EE, Al-Sweih N. Shifts in the clonal distribution of methicillin-resistant staphylococcus aureus in Kuwait hospitals: 1992-2010. PLoS ONE. 2016;11(9):e0162744 (in English).

179. Budimir A, Tićac B, Rukavina T, Farkaš M, Kalenić S. First report on PVLpositive methicillin-resistant Staphylococcus aureus of SCCmec type V, spa type T441 in Croatia. Coll Antropol. 2016;40(2):133-7 (in English).

180. Cabrera A, Golding G, Campbell J, Pelude L, Bryce E, Frenette C, et al. Characterization of clinical methicillin-resistant staphylococcus aureus (MRSA) isolates from Canadian hospitals, 2010-2015. Open Forum Infect Dis. 2016:3:1746 (in English).

181. Farrell DJ, Mendes RE, Castanheira M, Jones RN. Activity of fusidic acid tested against staphylococci isolated from patients in U.S. Medical Centers in 2014. Antimicrob Agents Chemother. 2016;60(6):3827-31.

182. Flamm RK, Rhomberg PR, Farrell DJ, Jones RN. In vitro spectrum of pexiganan activity; bactericidal action and resistance selection tested against pathogens with elevated MIC values to topical agents. Diagn Microbiol Infect Dis. 2016;86(1):66-9.

183. Harkins CP, McAleer MA, Fleury OM, Bennett D, Foster TJ, McLean WHI, et al. Staphylococcus aureus associated with atopic eczema flares: casecontrol study. Br J Dermatol. 2016;174(5):e43 (in English).

184. Klein S, Nurjadi D, Eigenbrod T, Bode KA. Evaluation of antibiotic resistance to orally administrable antibiotics in staphylococcal bone and joint infections in one of the largest university hospitals in Germany: is there a role for fusidic acid? Int J Antimicrob Agents. 2016;47(2):155-7.

185. Liu Y, Xu Z, Yang Z, Sun J, Ma L. Characterization of communityassociated Staphylococcus aureus from skin and soft-tissue infections: a multicenter study in China. Emerg Microbes Infect. 2016;5(12):e127.

186. Mehdi SZ, Akber JUD, Nizam M, Dawood K, Buksh AR. Frequency and antimicrobial susceptibility pattern of microorganisms isolated from hospitalized infantile burn cases in a tertiary care hospital. Pak Paediatr J. 2016;40(3):135-42 (in English).

187. Nawaz A, Razzaq A, ljaz S, Nawaz A, Ali A, Kaleem A. Characterization of antibiotic resistant gene in Staphylococcus aureus isolated from surgical wounds. Adv Life Sci. 2016;3(3):83-8.

188. Park JM, Jo JH, Jin H, Ko HC, Kim MB, Kim JM, et al. Change in antimicrobial susceptibility of skin-colonizing Staphylococcus aureus in Korean patients with atopic dermatitis during ten-year period. Ann Dermatol. 2016;28(4):470-8

189. Rahimi F, Shokoohizadeh L. Characterization of methicillin resistant Staphylococcus aureus strains among inpatients and outpatients in a referral hospital in Tehran, Iran. Microb Pathog. 2016;97:89-93 (in English).

190. Sarkar A, Raji A, Garaween G, Soge O, Rey-Ladino J, Al-Kattan W, et al. Antimicrobial resistance and virulence markers in methicillin sensitive Staphylococcus aureus isolates associated with nasal colonization. Microb Pathog. 2016;93:8-12.

191. Shahmohammadi MR, Nahaei MR, Akbarzadeh A, Milani M. Clinical test to detect mecA and antibiotic resistance in Staphylococcus aureus, based on novel biotechnological methods. Artif Cells Nanomed Biotechnol. 2016;44(6):1464-8.

192. Souli M, Karaiskos I, Galani L, Maraki S, Perivolioti E, Argyropoulou A, et al. Nationwide surveillance of resistance rates of Staphylococcus aureus clinical isolates from Greek hospitals, 2012-2013. Infect Dis. 2016;48(4):287-92 (in English).

193. Abouelfetouh A, Kassem M, Naguib M, El-Nakeeb M. Investigation and treatment of fusidic acid resistance among methicillin-resistant staphylococcal isolates from Egypt. Microb Drug Resist. 2017;23(1):8-17.

194. Aktas G, Derbentli S. In vitro activity of daptomycin combinations with rifampicin, gentamicin, fosfomycin and fusidic acid against MRSA strains. J Glob Antimicrob Resist. 2017;10:223-7 (in English).

195. Al Balawi I, Amirthalingam P, Alyoussef AAK, Mohammed OS, Mirghani HO, Ezzat AA. Antibiotic susceptibility pattern of methicillin-resistant 
Staphylococcus aureus from the isolated wound culture in the northwest region, Kingdom of Saudi Arabia. Asian J Pharm Res Health Care. 2017;9(1):1-6 (in English).

196. Błazewicz I, Jaśkiewicz M, Bauer M, Piechowicz L, Nowicki RJ, Kamysz W, et al. Decolonization of Staphylococcus aureus in patients with atopic dermatitis: a reason for increasing resistance to antibiotics? Postepy Dermatologii i Alergologii. 2017;34(6):553-60 (in English).

197. Doudoulakakis A, Spiliopoulou I, Spyridis N, Giormezis N, Kopsidas J, Militsopoulou M, et al. Emergence of a Staphylococcus aureus clone resistant to mupirocin and fusidic acid carrying exotoxin genes and causing mainly skin infections. J Clin Microbiol. 2017;55(8):2529-37.

198. Gostev V, Kruglov A, Kalinogorskaya O, Dmitrenko O, Khokhlova O, Yamamoto T, et al. Molecular epidemiology and antibiotic resistance of methicillin-resistant Staphylococcus aureus circulating in the Russian Federation. Infect Genet Evol J Mol Epidemiol Evolut Genet Infect Dis. 2017:53:189-94

199. Khemiri M, Akrout Alhusain A, Abbassi MS, El Ghaieb H, Santos Costa S, Belas A, et al. Clonal spread of methicillin-resistant Staphylococcus aureus-t6065-CC5-SCCmecV-agrll in a Libyan hospital. J Glob Antimicrob Resist. 2017;10:101-5 (in English)

200. Liu X, Deng S, Huang J, Huang Y, Zhang Y, Yan Q, et al. Dissemination of macrolides, fusidic acid and mupirocin resistance among Staphylococcus aureus clinical isolates. Oncotarget. 2017;8(35):58086-97 (in English).

201. Saleem F, Fasih N, Zafar A. Susceptibility pattern of methicillin resistant staphylococcus aureus to vancomycin and other alternate agents: report from a private sector hospital laboratory. J Pak Med Assoc. 2017;67(11):1743-6 (in English)

202. Udo EE, Al-Sweih N. Dominance of community-associated methicillinresistant Staphylococcus aureus clones in a maternity hospital. PLoS ONE. 2017;12(6):e0179563 (in English)

203. Udo EE, Boswihi SS. Antibiotic resistance trends in methicillin-resistant Staphylococcus aureus isolated in Kuwait hospitals: 2011-2015. Med Princip Pract Int J Kuwait Univ Health Sci Centre. 2017;26(5):485-90.

204. Wang JT, Huang IW, Chang SC, Tan MC, Lai JF, Chen PY, et al. Increasing resistance to fusidic acid among clinical isolates of MRSA. J Antimicrob Chemother. 2017;72(2):616-8.

205. Yilmaz ES, Aslantas O. Antimicrobial resistance and underlying mechanisms in Staphylococcus aureus isolates. Asian Pac J Trop Med. 2017;10(11):1059-64.

206. Boswihi SS, Udo EE, Monecke S, Mathew B, Noronha B, Verghese T, et al. Emerging variants of methicillin-resistant Staphylococcus aureus genotypes in Kuwait hospitals. PLoS ONE. 2018;13(4):e0195933 (in English).

207. Budri PE, Shore AC, Coleman DC, Kinnevey PM, Humpreys H, FitzgeraldHughes D. Observational cross-sectional study of nasal staphylococcal species of medical students of diverse geographical origin, prior to healthcare exposure: prevalence of SCCmec, fusC, fusB and the arginine catabolite mobile element (ACME) in the absence of selective antibiotic pressure. BMJ Open. 2018;8(4):e020391.

208. Çetinkol Y, Aladal M, Ünal N, Bayramoglu G, Ahmetbayik S, Dogan $\mathrm{M}$, et al. Comparison of fusidic acid susceptibility of staphylococci: a multicenter study. Acta Medica Mediterranea. 2018;34(2):397-402 (in English).

209. Edslev SM, Clausen ML, Agner T, Stegger M, Andersen PS. Genomic analysis reveals different mechanisms of fusidic acid resistance in Staphylococcus aureus from Danish atopic dermatitis patients. J Antimicrob Chemother. 2018;73(4):856-61.

210. Fong IL, Razak E, Mei JTJ, Safian NAB, Tian OS, Peng NP, et al. Prevalence and antibiotic sensitivity profiles of Staphylococcus aureus nasal carriage among preclinical and clinical medical students in a Malaysian university. Malays J Microbiol. 2018;14(4):351-5.

211. Huang YT, Liao CH, Chen SY, Yang CJ, Hsu HS, Teng LJ, et al. Characterization of rifampin-resistant Staphylococcus aureus nasal carriage in patients receiving rifampin-containing regimens for tuberculosis. Infect Drug Resist. 2018;11:1175-82 (in English).

212. Khan F, Ahmad B, Ahmed J, Yoo HS, Bashir S. Investigation of Staphylococcus aureus, prevailing in the environment of Khyber Teaching Hospital, Peshawar, Pakistan. Paki J Pharm Sci. 2018;31 (2):429-37.

213. Senok AC, Somily A, Raji M, Garaween G, Kabil M, Shibl A, et al. Genotyping of staphylococcus aureus associated with nasal colonization among healthcare workers using DNA microarray. J Infect Dev Ctries. 2018;12(5):321-5 (in English).

214. Sklyar TV, Lavrentieva KV, Gavrilyuk VG, Kurahina NV, Vereshchaha MO Lykholat OA. Monitoring of multiresistant community-associated MRSA strains from patients with pathological processes of different localization. Regul Mech Biosyst. 2018;9(2):281-6.

215. Sohail M, Latif Z. Molecular analysis, biofilm formation, and susceptibility of methicillin-resistant Staphylococcus aureus strains causing community-and health care-associated infections in central venous catheters. Rev Soc Bras Med Trop. 2018;51 (5):603-9 (in English).

216. Ahmadi E, Khojasteh M, Mortazavi SM, Khan-Mohammadi F, Kazemnia A, Beheshtipour J, et al. Prevalence of and risk factors for methicillin-resistant Staphylococcus aureus nasal carriage in the West of Iran: a population-based cross-sectional study. BMC Infect Dis. 2019;19(1):899

217. Aldasouqi R, Abu-Qatouseh L, Badran E, Alhaj Mahmoud S, Darwish M. Genetic determinants of resistance to fusidic acid among staphylococcus aureus isolates in Jordan. Jundishapur J Microbiol. 2019;12(3):e86120. (in English)

218. Alfouzan W, Udo EE, Modhaffer A, Alosaimi A. Molecular characterization of methicillin-resistant Staphylococcus aureus in a Tertiary Care hospital in Kuwait. Sci Rep. 2019;9(1):18527 (in English)

219. Conceicao T, Martins H, Rodrigues S, de Lencastre H, Aires-deSousa M. Staphylococcus aureus nasal carriage among homeless population in Lisbon, Portugal. Eur J Clin Microbiol Infect Dis. 2019;38(11):2037-44.

220. Coşun MV, Alper Y, Uyanık MH, Yazgı H. Sensitivity of methicillin-resistant staphylococcus aureus strains to fusidic acid and other non- $\beta$-lactam antibiotics. Klimik Dergisi. 2019;32(1):52-6 (in Turkish).

221. Davey RX, Tong SYC. The epidemiology of Staphylococcus aureus skin and soft tissue infection in the southern Barkly region of Australia's Northern Territory in 2017. Pathology. 2019;51 (3):308-12.

222. Frickmann H, Hahn A, Berlec S, Ulrich J, Jansson M, Schwarz NG, et al. On the etiological relevance of Escherichia coli and Staphylococcus aureus in superficial and deep infections-a hypothesis-forming, retrospective assessment. Eur J Microbiol Immunol. 2019;9(4):124-30 (in English)

223. Ghaith DM, Elnagdy SM, Tharwat NA, Said M. Expression of FusC gene Among methicillin resistant Staph aureus clinical isolates resistant to fusidic acid, Cairo. Egypt Infect Dis. 2019;51(11-12):878-9.

224. Hanif E, Hassan SA. Evaluation of antibiotic resistance pattern in clinical isolates of Staphylococcus aureus. Pak J Pharm Sci. 2019;32(3 (Supplementary)):1219-23.

225. Klein S, Menz MD, Zanger P, Heeg K, Nurjadi D. Increase in the prevalence of Panton-Valentine leukocidin and clonal shift in communityonset methicillin-resistant Staphylococcus aureus causing skin and soft-tissue infections in the Rhine-Neckar Region, Germany, 2012-2016. Int J Antimicrob Agents. 2019;53(3):261-7 (in English).

226. Razeghi M, Saffarian P, Goudarzi M. Incidence of inducible clindamycin resistance and antibacterial resistance genes variability in clinical Staphylococcus aureus strains: a two-year multicenter study in Tehran, Iran. Gene Rep. 2019;16:100411 (in English).

227. Salmanov AG, Shkorbotun VO, Shkorbotun YV. Antimicrobial resistance of staphylococcus aureus causing of surgical site infections in ear, nose and throat surgery. Wiadomosci lekarskie (Warsaw, Poland: 1960). 2019;72(2):154-8

228. Swathi G, Chandan KS, Murgesh SB. Clinical and bacteriological study of pyoderma with reference to antibiotic susceptibility profile. J Pak Assoc Dermatol. 2019;29(1):83-8 (in English).

229. Udo E, Boswihi S, AlFouzan W, Mathew B, Noronha B, Verghese T, et al. Stability of the dominant Methicillin-resistant Staphylococcus aureus clones in Kuwait hospitals in 2016-2017. J Infect Public Health. 2019;12(1):141 (in English).

230. Goudarzi M, Tayebi Z, Dadashi M, Miri M, Amirpour A, Fazeli M. Characteristics of community-acquired methicillin-resistant Staphylococcus aureus associated with wound infections in Tehran, Iran: High prevalence of PVL+ t008 and the emergence of new spa types t657, t5348, and t437 in Iran. Gene Rep. 2020;19:100603 (in English).

231. Senok A, Nassar R, Kaklamanos EG, Belhoul K, Abu Fanas S, Nassar $\mathrm{M}$, et al. Molecular characterization of Staphylococcus aureus isolates associated with nasal colonization and environmental contamination 
in academic dental clinics. Microb Drug Resist (Larchmont, NY). 2020;26:661-9. (in English).

232. Senok A, Somily A, Nassar R, Garaween G, Sing GK, Müller E, et al. Emergence of novel methicillin resistant Staphylococcus aureus strains in a tertiary care facility in Riyadh, Saudi Arabia. J Infect Public Health. 2020;13(2):322 (in English).

233. Udo E, AlFouzan W, Boloki H, Musaileem WA, Verghese T. Investigation of fusidic acid resistance determinants in methicillin-resistant Staphylococcus aureus obtained in Kuwait hospitals. I Infect Public Health. 2020;13(2):324 (in English).

234. Yu F, Liu Y, Lu C, Lv J, Qi X, Ding Y, et al. Dissemination of fusidic acid resistance among Staphylococcus aureus clinical isolates. BMC Microbiol. 2015:15:210.

235. Alreshidi MA, Mariana N. Increasing rate of detection of fusidic acid resistance in methicillin-resistant Staphylococcus aureus isolated from clinical samples in Malaysia. Med J Malays. 2011;66:276.

236. Chen C-M, Huang M, Chen H-F, Ke S-C, Li C-R, Wang J-H, et al. Fusidic acid resistance among clinical isolates of methicillin-resistant Staphylococcus aureus in a Taiwanese hospital. BMC Microbiol. 2011;11:1-8. https://doi.org/10.1186/1471-2180-11-98.
237. O'Neill AJ, Larsen AR, Skov R, Henriksen AS, Chopra I. Characterization of the epidemic European fusidic acid-resistant impetigo clone of Staphylococcus aureus. J Clin Microbiol. 2007;45(5):1505-10.

238. Liu Y, Geng W, Yang Y, Wang C, Zheng Y, Shang Y, et al. Susceptibility to and resistance determinants of fusidic acid in Staphylococcus aureus isolated from Chinese children with skin and soft tissue infections. FEMS Immunol Med Microbiol. 2012;64(2):212-8.

239. Brown E, Brown TP. Fusidic acid resistance in Staphylococcus aureus isolates. Lancet. 2002:359:803

240. Dobie D, Gray J. Fusidic acid resistance in Staphylococcus aureus. Arch Dis Child. 2004;89(1):74-7.

241. Farrell DJ, Castanheira M, Chopra I. Characterization of global patterns and the genetics of fusidic acid resistance. Clin Infect. 2011;52(Suppl 7):S487-92.

\section{Publisher's Note}

Springer Nature remains neutral with regard to jurisdictional claims in published maps and institutional affiliations.
Ready to submit your research? Choose BMC and benefit from:

- fast, convenient online submission

- thorough peer review by experienced researchers in your field

- rapid publication on acceptance

- support for research data, including large and complex data types

- gold Open Access which fosters wider collaboration and increased citations

- maximum visibility for your research: over $100 \mathrm{M}$ website views per year

At BMC, research is always in progress.

Learn more biomedcentral.com/submissions 